\title{
橈骨舟状骨間関節症に対する腱球移植術の経験
}

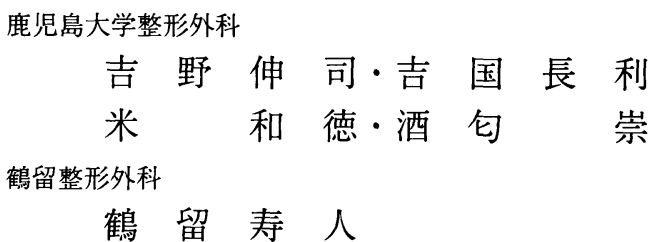

\section{Clinical Study of Arthroplasty Using a Coiled Tendon Grafting for Radioscaphoid Arthrosis}

by

\author{
Shinji Yoshino, Nagatoshi Yoshikuni, \\ Kazunori Yone and Takashi Sakou \\ Department of Orthopaedic Surgery, Faculty of Medicine, \\ Kagoshima University, Kagoshima, Japan \\ Hisato Tsurudome \\ Tsurudome Orthopaedic Clinic
}

\begin{abstract}
Osteoarthritis of the radioscaphoid joint (radioscaphoid arthrosis) is, a rare condition, caused by a scaphoid nounion, scapholunate advanced collapse (SLAC degeneration) and others. We reported about two cases of this disorder treated by arthroplasty using a coiled tendon grafting.

Case 1 had a chronic scaphoid nonunion, and case 2 had a chronic scapholunate advanced collapse deformity. Both cases had severe wrist pain and moition was significantly limited. X-rays showed degenerative changed in the radioscaphoid and scaphotrapezial-trapezoidal joints in both patients.

We performed radioscaphoid arthroplasty with partial scaphoid resection using a coiled tendon grafting, radial styloidectomy and scaphotarapezial-trapezoidal fusion. In case 2, capitolunate fusion was carried out additionally. Follow-up time was 9 months in case 1 , and 6.5 months in case 2. Preoperative pain was dramatically relieved in both patients, so they returned to preoperative occupations.

In conclusion, Arthroplasty using a coiled tendon grafting for radioscaphoid arthrosis is thought to be a reliable method to replace a segment of collapsed scaphoid.
\end{abstract}

橈骨舟状骨間関節症は舟状骨偽関節, Watson 5のい う Scapho-lunate advanced collapse (以下 SLAC 型関節症）などにより生じ, 治療に難渋する疾患であ $\Xi^{3)}$. 今回我々は本症例 2 例を経験し, 舟状骨腱球移 植により比較的良好な結果をえた。本治療法の適応, 問題点等につき検討を加えたので報告する.

症例

症例 1.55才 男性 左官業
既往例: 約 30 年前トラックの荷台から転落, 右手 関節の腫脹, 疼痛あるも放置, 自然緩解していた.

現病歴: 約 1 年前より右手関節痛出現, 近医にて保 存的に加療するも疼痛改善せず，当科受診す．

初診時所見 : 右手関節は背側中央部から橈側に腫脹, 軽度の熱感あり圧痛を認めた. 可動域は背屈 $40^{\circ}$, 掌 屈 $20^{\circ}$ と制限を認め, 握力も $14 \mathrm{~kg}$ (健側 $32 \mathrm{~kg}$ ) と 低下を認めた。

X-P 所見 : 舟状骨の偽関節形成, 舟状骨遠位一橈 
骨間及び舟状骨一大菱形骨間関節の OA 変化を認め た (図 1 a).

以上から本例は舟状骨偽関節の長期放置による橈骨 舟状骨間および舟状骨大菱形骨間関節症と診断し，手 術を施行した。

手術は壊死に陥った舟状骨近位骨片を摘出，同部に 長掌筋腱による腱球を挿入した。併せて橈骨茎状突 起切除，舟状一大・小菱形骨間固定を施行した。術後 9 カ月の現在, 手関節痛は消失, 可動域は背屈 $45^{\circ}$, 掌屈 $25^{\circ}$ と軽度の改善を認める. 握力も $20 \mathrm{~kg}$ と改善 を認め, 復職している(図 $1 \mathrm{~b}$ )。

症例 2.61 才男性 農業

既往歴 : 特記すべき事なし

現病歴: 約 1 年前から労作後の右手関節痛, 腫脹が 出現し近医受診，X-Pにて手関節の異常が指摘され 関節注入等にて加療するも, 疼痛増強し次第に可動域 制限が生じたため当科受診した。

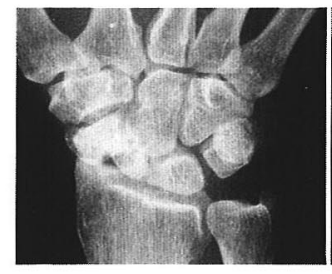

a

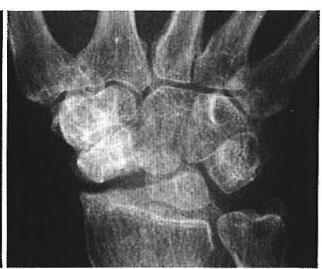

b
図 1 症例 1

a. 初診時 : 舟状骨偽関節, 舟状骨一橈骨間, 舟状骨一大菱形骨間の OA 変化を認める.

b. 術後 9 カ月: 腱球のスペースは保たれてい る.

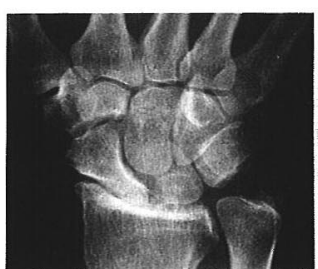

a

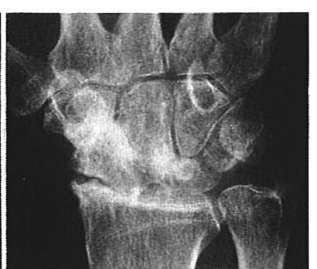

$\mathrm{b}$
圈 2 症例 2

a. 初診時 : 橈骨舟状骨間の著明な OA 変化, 舟状一舟状骨間の開大，有頭骨の proximal migrationを認める.

b. 術後6.5力月: 腱球スペースは狭い, 舟状 骨および橈骨茎状突起の切除不足がある.
初診時所見 : 右手関節背橈側に腫脹，熱感あり圧痛 も認めた，可動域は背屈 $40^{\circ}$ ，掌屈 $10^{\circ}$ と制限あり, 握力も $12 \mathrm{~kg}$ （腱側 $35 \mathrm{~kg}$ ）と低下していた.

X-P 所見 : 橈骨舟状骨間関節裂隙の狭少化, 関節 面の硬化，舟状骨月状骨間の開大および有頭骨の proximal migration を認めた。 また舟状骨一大・小畟 形骨間の OA 変化も認めた.

以上から本例は Watson らの提唱する SLAC 型関 節症と診断した（図 $2 a ）$.

手術は，著明な変性に陥った舟状骨の近位部を切除 し, 大腿筋膜を腱球として挿入, 橈骨茎上突起切除, 舟状一大 - 小菱形骨および有頭一月状骨固定を行った. 術後 6.5 力月の現在, 可動域は $40^{\circ}$, 掌屈 $15^{\circ}$ とほほ 術前と同様であるが，握力は $17 \mathrm{~kg}$ と改善し手関節痛 はなく復職している（図 $2 \mathrm{~b} ）$.

\section{考察}

舟状骨は手根骨の key bone ともいわれ，その損 傷により手関節機能は著しく障害される，本症例のよ うに，舟状骨偽関節の放置例， SLAC 型変性などで は，collapse に陥った舟状骨と橈骨間に関節症変化 を生じその治療には難渋する。これらの治療法として, 橈骨茎状突起切除, 舟状骨切除揖よび摘出, 舟状骨置 換術, proximal row carpectomy などが報告され ているが，未だ確立されていない，今回我々が行った 舟状骨部分切除と腱球置換術は, 舟状骨の粉砕骨折例 などで散見されるものの，まとまった報告はない，最 近, Eaton ら ${ }^{1)}$ が 20 例, 平均 3.8 年の経過報告をし, 良好な成績を示している，彼らは舟状骨以外の手根骨 間に関節症変化のあるものは適応外とし，また我々の ような部分手根骨固定は行っていない。しかし我々は 症例 1 では, 舟状骨一大菱形骨間関節症の存在と残存 舟状骨の安定性を考え舟状一大・小菱形骨固定を行っ た．また症例 2 では有頭骨の proximal migration を防止すると共に負荷を月状骨へ分散させるという Watson ら ${ }^{2)}$ の考えに従い有頭一月状骨固定も行った. 術後可動域の改善がそしいが，これは手根骨固定の影 響と思われる．本症例で施行した部分手根骨固定の手 関節機能に与える影響は，諸家が報告しているように

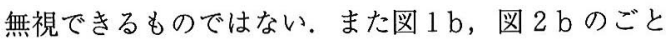
く, 術後 X-P を比較すると, 症例 2 は舟状骨の切除 不足，茎状突起の残存があり現在の可動域制限に関係 
していると考えられる。実際，症例 2 では掌屈時, lockするような印象があり, 舟状骨と茎状突起間で impingement が生じていると思われた. 症例 1 は腱 球のスペースも保たれ, 舟状骨の置換材料として十分 役割を果たしていると考えられた.

橈骨舟状骨間関節症は比較的稀れであるが, 本症例 のように collapse に陥った舟状骨を腱球を用い部分 置換することで十分に対応できると思われる.

$$
\text { ま と め }
$$

(1)舟状骨偽関節，SLAC 型関節症により橈骨舟状 骨間関節症の 2 例について報告した.

(2)変形, 変性した舟状骨を部分切除し, 腱球を用い て置換した．併せて部分手根骨固定も行った。

(3)術後手関節痛は消失, 労働作業に復職し, 比較的 良好な結果を得た。

(4)腱球置換術は collapseに陥った舟状骨の置換方 法として有用であると思われた.

\section{文献}

1) Eaton, R.G.: Fascial implant arthroplasty for treatment of radioscaphoid degenerative disease. J. Hand surg. 14A : 766-774, 1989.

2) Watson, H.K.: The SLAC wrist: Scapho-lunate advanced collapse pattern of dege nerative arthritis. J. Hand surg. 9 A : 358-365, 1984.

3) Lichtman, D.M.: The wrist and its disorders. Saunders, Philadelphis, 1988.

追 加北里大学 二見 俊郎

腱球を挿入されるのは，力学的修復を期待されてお られるのか？ 腱球のみでは collapse を防止できに くいと思われますが.

\section{解 答鹿児島大学 吉野 伸司}

力学的, 機能的には腱球でも十分とは考えないが, 切除した舟状骨のスペースを保つために，使用しやす い腱球を用いた。 